\title{
Protein requirements in tropical countries: nitrogen losses in sweat and their relation to nitrogen balance
}

\author{
By ANN ASHWORTH \\ Medical Research Council, Tropical Metabolism Research Unit, \\ University of the West Indies, Famaica \\ AND A. D. B. HARROWER \\ University of Edinburgh Medical School, Edinburgh \\ (Received ${ }_{27}$ February 1967-Accepted 8 fune 1967)
}

\begin{abstract}
1. An experiment was undertaken to determine whether high rates of sweating in a tropical climate affect protein requirements by increasing the total nitrogen losses from the body.

2. Six fully acclimatized volunteers were given a diet supplying $5 \circ \mathrm{g}$ protein $(=8 \mathrm{~g} \mathrm{~N})$ daily. 'They performed strenuous physical work of a normal nature for an average of $6 \frac{1}{2} \mathrm{~h}$ a day for two 5-day periods. During control periods the subjects took minimal exercise and lived in a cool environment. $\mathrm{N}$ balance was measured throughout.

3. Rates of sweating were measured by weighing. Whole body sweat was collected and the concentrations were measured of nitrogen, sodium and potassium. During $6 \frac{1}{2} \mathrm{~h}$ work approximately $3 \mathrm{l}$. of sweat were lost, containing on average $0.49 \mathrm{~g} \mathrm{~N}, 64 \mathrm{~m}$-equiv. $\mathrm{Na}$ and $22 \mathrm{~m}$ equiv. $\mathrm{K}$.

4. The $\mathrm{N}$ concentration in sweat was $0.20 \mathrm{mg} / \mathrm{g}$, which is lower than that found by most other workers. It is suggested that acclimatization is an important factor in reducing $N$ loss by sweating.

5. There was a marked decrease in urinary $\mathrm{Na}$ excretion during sweating, which compensated fully for the loss of $\mathrm{Na}$ in sweat. Renal compensation for loss of $\mathrm{K}$ was less efficient.

6. Because the total $N$ loss in sweat was small, it was not possible to establish with certainty whether it was compensated for by a reduced renal excretion of $\mathbf{N}$. However, after the initial period the subjects were in $\mathrm{N}$ balance in spite of the relatively low protein intake.

7. It is concluded that there is no evidence to suggest that heavy sweating under natural conditions in a tropical climate causes a significant increase in protein requirements.
\end{abstract}

Recently suggestions have been put forward that protein requirements may be higher in tropical than in temperate countries because of the loss of nitrogen in sweat. Consolazio, Nelson, Matoush, Harding \& Canham (1963) have proposed that protein allowances should be increased by $1_{3}-14 \%$, whilst Mitchell \& Edman (1962) state that increases of the order of $20-30 \%$ are necessary.

Consolazio, Nelson et al. (1963) based their proposals on studies carried out in an environmental chamber at $85^{\circ}$ and $100{ }^{\circ} \mathrm{F}$ in Denver, Colorado. During $7 \frac{1}{2}$ h sweating at $85^{\circ} \mathrm{F}$ eight young men lost on average $\mathrm{I}_{8} \mathrm{I}_{5} \mathrm{~g}$ of sweat containing $\mathrm{I} \cdot 4 \mathrm{I} 8 \mathrm{~g} \mathrm{~N}$. When three young men spent $2 \mathrm{I} \mathrm{h}$ at $100^{\circ} \mathrm{F}$, it was estimated that they would each lose over $4 \mathrm{~g} N /$ day. Furthermore, the $\mathrm{N}$ losses in sweat were not compensated for by decreased losses of $\mathrm{N}$ in urine or faeces. In fact, at $100^{\circ} \mathrm{F}$ the subjects were in negative $\mathrm{N}$ balance throughout the I 6 days of the experiment, even though their daily $\mathrm{N}$ intakes were ${ }_{1} 3.6 \mathrm{~g}(84.4 \mathrm{~g}$ protein). If these findings are applied to people living and working in tropical climates it would be impossible for them to maintain health and $\mathrm{N}$ balance, as in fact they do, on daily intakes of about $60 \mathrm{~g}$ protein. 
There are three possible explanations for the large $\mathrm{N}$ losses in the sweat and the negative $\mathrm{N}$ balances of Consolazio's subjects. (I) The subjects were not acclimatized; for example, during the $\mathrm{I} 6$ days at $100{ }^{\circ} \mathrm{F}$ the $\mathrm{N}$ concentration of the sweat decreased from I.00 to $0.53 \mathrm{mg} \mathrm{N} / \mathrm{g}$ sweat. (2) $\mathrm{N}$ was measured only in arm sweat, and this may not be representative of total body sweat. (3) The environmental chamber may have constituted a stress situation. This could have the effect of increasing the urinary $\mathrm{N}$ output (Scrimshaw, Habicht, Piché, Cholakos \& Arroyave, 1966) and may have masked any simultaneous compensatory decrease in urinary $\mathrm{N}$ when sweating.

The study reported here had two objects: to find the extent of $\mathrm{N}$ losses in sweat in a group of acclimatized people undergoing fairly strenuous, but natural, physical work, in a hot climate; and to determine whether the increased loss of $\mathrm{N}$ in sweat was compensated for by a decreased urinary $\mathrm{N}$ output, as would be expected on physiological grounds.

\section{EXPERIMENTAL}

The study was carried out at the Tropical Metabolism Research Unit of the Medical Research Council, University of the West Indies, Jamaica, in August 1966. At this time the mean maximum temperature was $9 I^{\circ} \mathrm{F}$, and the mean relative humidity $83 \%$.

The volunteers were six male medical students aged 20-26 years. Of these, five were West Indian and fully acclimatized to tropical conditions. The sixth (A.H.) was Scottish and had been in Jamaica for 3 weeks competing in the Commonwealth Games.

The experiment lasted for 20 days and was divided into four periods, each of 5 days. The first and third periods were designed to be ones of minimal sweating; the subjects spent about $9 \mathrm{~h}$ each day sitting quietly, often in air-conditioned rooms at $73{ }^{\circ} \mathrm{F}$. During the remainder of the day they were allowed to go home but were asked to keep physical activity to a minimum. The second and final periods were ones of heavy sweating with hard physical work outdoors for about $7 \mathrm{~h}$ each day at temperatures of $83-92{ }^{\circ} \mathrm{F}$. The work was of a normal nature and included athletics, cycling, badminton, football, polishing cars, mowing lawns and clearing bush. During the second and fourth periods no restrictions on activity were imposed when the subjects went home in the evenings.

\section{Balance studies}

Diets. All meals were prepared and eaten at the Unit and every item of food was weighed. Menus were planned to provide a daily intake of $7 \cdot 5^{-8} \cdot \circ \mathrm{g} \mathrm{N}$, which corresponds to the average protein intake of $40-50 \mathrm{~g}$ found among rural Jamaicans. This moderate intake of $\mathrm{N}$ was also chosen so that the total urinary $\mathrm{N}$ output would be fairly small, and therefore any compensatory decrease in urinary $\mathrm{N}$ during the heavysweating periods would be more noticeable.

Five menus were used and were repeated for each period. All the subjects received identical meals, and foods were chosen which were homogeneous and from which there would be no waste. In order to assess the dietary intake accurately, an additional identical meal was put each time into a polythene bag, one bag being used per day. These bags containing each day's food were then deep-frozen and subsequently 
analysed for $\mathrm{N}$, water content, sodium and potassium. Salt $(\mathrm{NaCl})$ was allowed $a d$ lib. each subject having his own salt-cellar, which was weighed at the beginning and end of each day. There were no appreciable changes in body-weight during the 20 days of the study. The subjects were offered sweets (fruit drops) to take home in the evening and a record was kept of the number eaten.

Water and other $\mathrm{N}$-free drinks were taken $a d$ lib. The volume and nature of the drinks were carefully recorded, and samples were analysed for $\mathrm{Na}$ and $\mathrm{K}$.

Urinary and faecal collections. Complete daily collections were made of urine and faeces throughout the experiment. The urine was preserved with hibitane and analysed for $\mathrm{N}, \mathrm{Na}$ and $\mathrm{K}$. The faeces were frozen; later two or three consecutive collections of the same period were bulked together for each person and homogenized. The $\mathrm{N}$ and water contents were determined on samples of the homogenate.

Water balance. The subjects were assumed to be in water balance, so intake and output of water were taken to be equal:

water intake $=$ fluid intake + water content of food + metabolic water;

water output $=$ urine + water content of faeces + insensible loss + sweat.

Fluid intake and urine output were measured directly. The water contents of food and faeces were estimated by drying suitable samples and metabolic water was calculated from the formula:

$$
\text { metabolic water }=0.4 \mathrm{I} \text { protein }+0.60 \text { carbohydrate }+\mathrm{I} \cdot 07 \text { fat }
$$

(Consolazio, Johnson \& Pecora, I963). The protein content of the food was determined by analysis and the carbohydrate and fat contents were calculated from food tables. The difference between input and output was therefore a measure of the total daily insensible water loss during the minimal-sweating periods and a measure of insensible loss + sweat during the heavy-sweating periods.

\section{Measurement and collection of sweat}

In addition to the balance technique of estimating insensible water and sweat losses, direct measurements were also made by measuring the change in body-weight. In both the minimal- and heavy-sweating periods, the change in body-weight included loss of $\mathrm{CO}_{2}$ as well as loss of water, but the $\mathrm{CO}_{2}$ loss would be relatively so small that it could be ignored.

Minimal sweating. During the first and third periods, when sweating was minimal, insensible water loss was measured in the morning and in the afternoon. The subjects were weighed at the beginning and end of each session on a beam balance to within $5 \mathrm{~g}$. Each was provided with a polythene water bottle, an empty polythene bottle for urine and an empty waxed carton for faeces, which were also weighed at the beginning and end of each session. The insensible water loss was taken to be the decrease in bodyweight, after the amount of water drunk and the amounts of urine and faeces produced had been taken into account.

Heavy sweating. The gross sweat loss during the heavy-sweating periods was measured in the same way by the change in body-weight. The difference between the 
gross sweat loss and the insensible water loss was taken to be the 'net' sweat loss. Except when otherwise stated, calculations were based on the 'net' sweat figures thereby minimizing the slight error of including the $\mathrm{CO}_{2}$ loss in the change in body-weight. Sweating rates were calculated separately for each morning and afternoon session.

In the afternoons of the sweating periods, the sweat from the whole body was collected in order to measure the $N$ concentration and to assess the extent of the $\mathrm{N}$ losses. The subjects had a shower and then put on $\mathrm{N}$-free cotton shirts, underpants and shorts. When exercising and sweating profusely they continually wiped themselves down with a $\mathrm{N}$-free towel to avoid sweat accumulating and splashing off the arms and legs.

At the end of the afternoon session they were given a bucket containing about 41 . of deionized acidified water and another towel. They then wet this towel with the water and carefully wiped themselves all over to remove evaporated sweat. The towel was rinsed in the water and the process was repeated many times with great thoroughness. The clothes and both towels were then put in the bucket and left to soak for $24 \mathrm{~h}$.

After soaking, the bucket and contents were weighed, and by subtracting the initial weight of the bucket and dry clothes, the weight of water + sweat was obtained. The specific gravity of this water + sweat solution was not significantly greater than $\mathrm{I} \cdot \circ$, and so the volume of the solution was taken to be the same as its weight. The clothes were vigorously prodded and stirred with a metal rod for Io min so that the sweat $\mathrm{N}$ and electrolytes were dissolved and distributed evenly through the solution. This method was tested by comparing it with repeatedly washing the clothes and was found to be a satisfactory way of eluting the sweat solids.

Portions $(20 \mathrm{ml})$ were taken for Kjeldahl analysis, and from the total volume of the solution the amount of $\mathrm{N}$ lost during the afternoon sweating session was calculated. The concentration of $\mathrm{N}$ in $\mathrm{mg} / \mathrm{g}$ was found by dividing the total $\mathrm{N}$ in the sweat (in $\mathrm{mg}$ ) by the 'net' sweat loss (in g).

There was little daily variation in $\mathrm{N}$ concentration, and the morning $\mathrm{N}$ losses were estimated by multiplying the 'net' sweat loss of the morning session by the mean afternoon $\mathrm{N}$ concentration. Samples of eluted sweat were also taken for $\mathrm{Na}$ and $\mathrm{K}$ analysis; the total losses in m-equiv. of $\mathrm{Na}$ and $\mathrm{K}$ were similarly calculated for the morning and afternoon sessions. $\mathrm{N}$ was measured by microKjeldahl, $\mathrm{Na}$ and $\mathrm{K}$ by flame photometry.

\section{RESULTS}

\section{Dietary intakes}

The mean daily intakes of $\mathrm{N}, \mathrm{Na}$ and $\mathrm{K}$ for the four periods are shown in Tables 6 , 7 and 8 respectively. The figures represent total intakes from food, table salt and additional drinks.

The amount of table salt consumed was fairly constant for each subject, and there was no difference in the amount consumed between the sweating and non-sweating periods. There were, however, considerable individual differences, with some subjects consuming four times as much salt as others. 


\section{Quantities of sweat produced}

The amount of time spent in hard physical work showed little individual or daily variation during periods 2 and 4 , and averaged $6.86 \mathrm{~h} /$ day in the first heavy-sweating period (period 2) and $6.45 \mathrm{~h} /$ day in the second heavy-sweating period (period 4 ). The gross amount of sweat produced averaged $3432 \mathrm{~g}$ in period 2 and $3389 \mathrm{~g} /$ day in period 4. In the minimal-sweating periods (periods $I$ and 3 ) the mean insensible water losses of the subjects were $57^{6}$ and $504 \mathrm{~g}$ respectively. The individual figures for insensible water loss and gross sweat loss in the four periods are shown in Table $\mathbf{I}$. The figures were obtained from the changes in body-weight in the morning plus afternoon sessions, after allowance had been made for water drunk and other factors.

Table I. Mean insensible water loss $(g)$ in periods $\mathrm{I}$ and 3 and gross sweat loss $(\mathrm{g})$ in periods 2 and 4

$\begin{array}{lcccc} & \begin{array}{c}\text { Period I. } \\ \text { Minimal- } \\ \text { sweating } \\ \text { insensible } \\ \text { loss }\end{array} & \begin{array}{c}\text { Period 2. } \\ \text { Heavy- } \\ \text { sweating } \\ \text { gross } \\ \text { loss }\end{array} & \begin{array}{c}\text { Period 3. } \\ \text { Minimal- } \\ \text { sweating } \\ \text { insensible } \\ \text { loss }\end{array} & \begin{array}{c}\text { Period 4. } \\ \text { Heavy- } \\ \text { sweating } \\ \text { gross } \\ \text { loss }\end{array} \\ \text { A. H. } & 756 & 3157 & 470 & 2765 \\ \text { D. W. } & 486 & 3007 & 627 & 3526 \\ \text { F. B. } & 647 & 4078 & 504 & 3728 \\ \text { C. C. } & 567 & 3732 & 483 & 4119 \\ \text { N. M. } & 599 & \mathbf{3 1 3 8} & 565 & 3047 \\ \text { L. C. } & 401 & 348 \text { I } & 376 & 3148 \\ \text { Mean } & 576 & 3432 & 504 & 3389\end{array}$

Table 2. Mean insensible sweat rate during minimal sweating and mean gross sweat rate and ' $n e t$ ' sweat rate during heavy sweating $(\mathrm{g} / \mathrm{h})$

$\begin{array}{lccc}\text { Subject } & \begin{array}{c}\text { Periods } \\ \text { I and } 3 . \\ \text { Insensible } \\ \text { sweat rate }\end{array} & \begin{array}{c}\text { Gross sweat } \\ \text { rate }\end{array} & \begin{array}{c}\text { 'Net' sweat } \\ \text { rate }\end{array} \\ \text { A. H. } & 93 & 462 & 369 \\ \text { D. W. } & 88 & 465 & 377 \\ \text { F. B. } & 93 & 579 & 486 \\ \text { C. C. } & \mathbf{8 2} & 605 & 523 \\ \text { N. M. } & 92 & 460 & 368 \\ \text { L. C. } & 67 & \mathbf{5 2 5} & 458 \\ \text { Mean } & 86 & \mathbf{5 1 6} & 430\end{array}$

When the sweat losses during periods 2 and 4 were calculated indirectly from the water balances, the mean values were 3355 and $3353 \mathrm{~g}$ sweat/day respectively, which gave good agreement with the direct measurements $\left(343^{2}\right.$ and $\left.33^{89} \mathrm{~g}\right)$. The indirect measurements refer to the amount of sweat lost during $24 \mathrm{~h}$, whereas the direct measurements apply only to the morning and afternoon sessions. Since the two are similar there must have been no appreciable sweat loss apart from that during the 
sweating sessions. The water-balance measurements were considered to be an important safeguard in checking whether any sweating occurred during the evenings after the subjects had left the controlled conditions of the Unit.

\section{Sweat rates}

The insensible sweat rate in $\mathrm{g} / \mathrm{h}$ was calculated, and a mean taken for the ro days of minimal sweating (Table 2). Similarly, the gross sweat rate during the heavysweating periods was calculated and a mean taken. The difference represents the 'net' sweat rate during heavy sweating. These values are shown in Table 2. They show remarkably little variation between the individual subjects.

Table 3. Mean daily nitrogen losses in sweat and $N$ concentration in sweat during heavy sweating

\begin{tabular}{|c|c|c|c|c|}
\hline \multirow[b]{2}{*}{ Subject } & \multicolumn{2}{|c|}{ Period 2} & \multicolumn{2}{|c|}{ Period 4} \\
\hline & $\begin{array}{l}\text { Loss of } N \\
\text { (g/day) }\end{array}$ & $\begin{array}{c}N \text { concentration } \\
(\mathrm{mg} / \mathrm{g})\end{array}$ & $\begin{array}{c}\text { Loss of } N \\
\text { (g/day) }\end{array}$ & $\begin{array}{c}N \text { concentration } \\
(\mathrm{mg} / \mathrm{g})\end{array}$ \\
\hline A. $\mathrm{H}$. & 0.663 & 0.26 & 0.572 & 0.26 \\
\hline D. W. & $0.44 I$ & 0.17 & 0.442 & 0.15 \\
\hline F. B. & $0.66 \mathrm{I}$ & 0.19 & 0.699 & 0.23 \\
\hline C. C. & 0.639 & 0.20 & 0.691 & 0.20 \\
\hline N. M. & 0.223 & 0.17 & 0.189 & 0.17 \\
\hline L. C. & 0.339 & 0.21 & 0.296 & 0.23 \\
\hline Mean & 0.494 & 0.20 & 0.482 & 0.21 \\
\hline
\end{tabular}

Table 4. Mean daily urinary nitrogen excretion $(g)$ for the four periods

$\begin{array}{lcccc}\text { Subject } & \begin{array}{c}\text { Period 1. } \\ \text { Minimal- } \\ \text { sweating }\end{array} & \begin{array}{c}\text { Period 2. } \\ \text { Heavy- } \\ \text { sweating }\end{array} & \begin{array}{c}\text { Period 3. } \\ \text { Minimal- } \\ \text { sweating }\end{array} & \begin{array}{c}\text { Period 4. } \\ \text { Heavy- } \\ \text { sweating }\end{array} \\ \text { A. H. } & 8.56 & 6.89 & 7.76 & 6.58 \\ \text { D. W. } & 6.61 & 6.05 & 5.62 & 6.18 \\ \text { F. B. } & 9 \cdot 23 & 8.42 & 5.83 & 6.01 \\ \text { C. C. } & 7.10 & 6.22 & 5.85 & 5.87 \\ \text { N. M. } & 7.98 & 5.99 & 6.09 & 5 \cdot 18 \\ \text { L. C. } & 8.22 & 6.77 & 8.48 & 6.75 \\ \text { Mean } & 7.95 & 6.72 & 6.61 & 6.10\end{array}$

\section{Nitrogen losses}

Sweat $N$. The total $\mathrm{N}$ lost in sweat per day whilst the subjects were performing hard physical work averaged $0.494 \mathrm{~g}$ and $0.482 \mathrm{~g}$ during periods 2 and 4 respectively.

The $\mathrm{N}$ concentration of the 'net' sweat in these two periods averaged $0.20 \mathrm{mg} / \mathrm{g}$ in period 2 and $0.21 \mathrm{mg} / \mathrm{g}$ in period 4 . Figures for the individual concentrations and total sweat $\mathrm{N}$ losses are shown in Table 3 .

Urinary $N$. The daily urinary excretion of $\mathrm{N}$ averaged $7 \cdot 95,6 \cdot 72,6 \cdot 6 \mathrm{I}$ and $6 \cdot 10 \mathrm{~g}$ for the four periods. The individual excretions are shown in Table 4.

Faecal $N$. The amount of $\mathrm{N}$ in the faeces was relatively large because of the quantity of fruit and vegetables eaten. The individual values for the four periods are shown in Table 5 . 


\section{Nitrogen balance}

$\mathrm{N}$ balances for the four periods are given in Table 6 . During period I balances were negative because of the change to a lower protein intake than that provided by the usual diet, but for the remainder of the study most of the subjects were in slightly positive $\mathrm{N}$ balance. The daily $\mathrm{N}$ balances for the four periods averaged -0.65 , $-0.16,+0.29$ and $+0.47 \mathrm{~g}$ respectively.

Table 5. Mean daily faecal nitrogen loss ( $g$ ) for the four periods

$\begin{array}{lcccc}\text { Subject } & \begin{array}{c}\text { Period I. } \\ \text { Minimal- } \\ \text { sweating }\end{array} & \begin{array}{c}\text { Period 2. } \\ \text { Heavy- } \\ \text { sweating }\end{array} & \begin{array}{c}\text { Period 3. } \\ \text { Minimal- } \\ \text { sweating }\end{array} & \begin{array}{c}\text { Period 4. } \\ \text { Heavy- } \\ \text { sweating }\end{array} \\ \text { A. H. } & \mathrm{I} \cdot \mathbf{1 7} & 0.54 & 0 \cdot 97 & \mathrm{I} \cdot 29 \\ \text { D. W. } & 0.66 & \mathrm{I} \cdot 24 & \mathrm{I} \cdot 44 & \mathrm{I} \cdot 36 \\ \text { F. B. } & \mathrm{I} \cdot 66 & \mathrm{I} \cdot 82 & \mathrm{I} \cdot 52 & \mathrm{I} \cdot 90 \\ \text { C. C. } & \mathrm{I} \cdot 52 & \mathrm{I} \cdot 27 & \mathrm{I} \cdot 0 \mathrm{I} & \mathrm{I} \cdot 46 \\ \text { N. M. } & 0.96 & \mathrm{I} \cdot 52 & \mathrm{I} \cdot 37 & \mathrm{I} \cdot 79 \\ \text { L. C. } & 0.83 & \mathrm{I} \cdot 45 & \mathrm{I} \cdot 08 & \mathrm{I} \cdot \mathrm{I} \mathbf{\mathrm { I }} \\ \quad \text { Mean } & \mathrm{I} \cdot \mathrm{I} 3 & \mathrm{I} \cdot 3 \mathrm{I} & \mathrm{I} \cdot 23 & \mathrm{I} \cdot 48\end{array}$

Table 6. Mean nitrogen balances ( $g / d a y$ ) for the four periods

\begin{tabular}{cccccc} 
& & \multicolumn{3}{c}{} & Sutput \\
\cline { 3 - 4 } Period & Intake & Urine & Faeces & Sweat & Balance \\
I & 8.43 & 7.95 & $1 \cdot 13$ & - & -0.65 \\
2 & 8.36 & 6.72 & 1.31 & 0.49 & -0.16 \\
3 & 8.13 & 6.61 & 1.23 & - & +0.29 \\
4 & 8.53 & 6.10 & 1.48 & 0.48 & +0.47
\end{tabular}

Table 7. Mean daily urinary sodium loss and intake (m-equiv.) for the four periods

$\begin{array}{cccc}\begin{array}{c}\text { Period I. } \\ \text { Minimal- } \\ \text { sweating }\end{array} & \begin{array}{c}\text { Period 2. } \\ \text { Heavy- } \\ \text { sweating }\end{array} & \begin{array}{c}\text { Period 3. } \\ \text { Minimal- } \\ \text { sweating }\end{array} & \begin{array}{c}\text { Period 4. } \\ \text { Heavy- } \\ \text { sweating }\end{array} \\ \text { I65 } & 91 & 213 & 121 \\ \text { I65 } & 102 & 154 & 109 \\ \text { I56 } & 78 & 161 & 66 \\ \text { I61 } & 77 & 167 & 66 \\ \text { I44 } & 90 & 214 & 91 \\ \text { I42 } & 61 & 152 & 78 \\ \text { I55 } & 83 & 177 & 88 \\ & & & \\ 183 & 179 & 183 & 175\end{array}$

\section{Sodium losses}

Sweat $\mathrm{Na}$. The mean amounts of $\mathrm{Na}$ lost per day in the sweat during the second and fourth heavy-sweating periods were 70 and $59 \mathrm{~m}$-equiv. and the corresponding $\mathrm{Na}$ concentrations were 19 and $17 \mathrm{~m}$-equiv./1.

Urinary $\mathrm{Na}$. The daily $\mathrm{Na}$ loss in the urine averaged $\mathrm{I}_{55}, 83, \mathrm{I} 77$ and $88 \mathrm{~m}$-equiv. for the four periods. The individual excretions are shown in Table 7 . 


\section{Potassium losses}

Sweat $K$. The daily amount of K lost in sweat averaged 27 and $18 \mathrm{~m}$-equiv. for the second and fourth heavy-sweating periods. The average concentrations were $7 \cdot 7$ and $5 \cdot 2$ m-equiv./1.

Urinary $K$. The daily $K$ loss in the urine averaged 84,78 , Ior and 70 m-equiv. for the four periods. Individual excretions are shown in Table 8.

Table 8. Mean daily urinary potassium loss and intake (m-equiv.) for the four periods

$\begin{array}{ccccc}\text { Subject } & \begin{array}{c}\text { Period I. } \\ \text { Minimal- } \\ \text { sweating }\end{array} & \begin{array}{c}\text { Period 2. } \\ \text { Heavy- } \\ \text { sweating }\end{array} & \begin{array}{c}\text { Period 3. } \\ \text { Minimal- } \\ \text { sweating }\end{array} & \begin{array}{c}\text { Period 4. } \\ \text { Heavy- } \\ \text { sweating }\end{array} \\ \text { A. H. } & 85 & 89 & \text { I 16 } & 77 \\ \text { D. W. } & 74 & 83 & 91 & 72 \\ \text { F. B. } & 88 & 75 & 84 & 58 \\ \text { C. C. } & 87 & 66 & 98 & 69 \\ \text { N. M. } & 90 & 70 & \text { IO2 } & 66 \\ \text { L. C. } & 82 & 84 & \text { II3 } & 80 \\ \text { Mean } & 84 & 78 & \text { I0I } & 70 \\ \text { urinaty loss } & & & & \\ \text { Mean intake } & \text { I 10 } & \text { I09 } & & \end{array}$

\section{DISCUSSION}

During the sweating periods of this study the sweat loss was approximately 31 . day The level of activity and exposure to the sun can be considered equivalent to that experienced by people in the more arduous manual occupations in Jamaica, such as cane-cutters and other farm workers, road and building construction workers and quarrymen. This rate of sweating may therefore be regarded as typical of the rates to be expected in tropical climates among people engaged in heavy outdoor work. In the more exceptional conditions of the desert, however, sweat losses are about twice as great at corresponding levels of activity (Molnar, Towbin, Gosselin, Brown \& Adolph, 1946).

When the results of Consolazio's study made in Denver, Colorado (Consolazio, Nelson et al. I963) and those of this study in Jamaica are compared, the Jamaican subjects had considerably lower $\mathrm{N}$ concentrations in sweat than the Denver subjects ( 0.20 compared with $0.78 \mathrm{mg} \mathrm{N} / \mathrm{g}$ ). This meant that, although the Jamaican subjects produced over one and a half times as much sweat, their total $\mathrm{N}$ loss in sweat was much less (0.49 compared with $\mathrm{I} \cdot 42 \mathrm{~g} /$ day).

Widely varying sweat $\mathrm{N}$ concentrations, averaging from 0.23 to $\mathrm{I} \cdot 4 \mathrm{I} \mathrm{mg} / \mathrm{g}$, have been reported by different investigators. These results have been summarized by Robinson \& Robinson (1954) in an excellent review on the chemical composition of sweat. One possible explanation for this wide range is the variety of methods used for sweat collection, such as enveloping the arm and hand in impermeable bags or collecting sweat from the whole body by washing the skin and clothing. For example, van Heyningen \& Weiner (1952), measuring chloride, lactate and urea concentrations, 
found that sweat collected in arm bags was consistently more concentrated than sweat from the whole body. Mickelsen \& Keys (1943) measured chloride concentrations and found sweat from the arm and hand to be more concentrated than total body sweat. The same was true of Na, K and N (Kleeman, Bass \& Quinn, 1953). Ladell (1948) found no significant differences in chloride concentrations between arm-bag sweat and total body sweat, but he did report that arm-bag sweat had a greater chloride concentration than sweat from a non-enveloped arm. In a recent study Consolazio, Matoush, Nelson, Isaac \& Canham (1966) found the mean Ca and $\mathrm{N}$ losses to be 38 and $11 \%$ higher, respectively, in arm-bag sweat than in total body sweat. They recommend that in future studies sweat should if possible be collected from the whole body. The fact that arm-bag collections were used in the Denver study and total sweat was collected in the Jamaica study may be one reason for the difference in the sweat $\mathrm{N}$ concentrations.

Another, and probably more important, factor overlooked in many studies is that of acclimatization. In previous work on nutrient losses in sweat relatively little importance has been attached to acclimatization, and often no information is given on whether subjects were acclimatized or not. The importance of this factor can be seen when one considers that in the Denver study (Consolazio, Nelson et al. 1963), the mean sweat $\mathrm{N}$ concentration decreased from $\mathrm{I} .00$ to $0.53 \mathrm{mg} / \mathrm{g}$ during $\mathrm{I} 6$ days at $100^{\circ} \mathrm{F}$. Bass, Kleeman, Quinn, Henschel \& Hegnauer (1955), in their studies on acclimatization, found that the $\mathrm{N}$ concentration in the sweat of five men fell from 0.64 to $0.27 \mathrm{mg} / \mathrm{g}$ after 9 days at $120^{\circ}$, whilst the concentration of $\mathrm{Na}$ decreased from 105 to $74 \mathrm{~m}$ equiv./l. and that of K from 8.2 to $4.2 \mathrm{~m}$-equiv./1. Daly \& Dill (1937) found striking decreases in $\mathrm{Na}$ and chloride concentrations with acclimatization but no change in $\mathrm{K}$ and $\mathrm{N}$ concentrations.

It is perhaps pertinent that in the present study the only non-resident in the tropics (A. H.) had the highest sweat $\mathrm{N}$ concentration $(0.26$ compared with $0.20 \mathrm{mg} / \mathrm{g}$ for the residents). The other subjects were already acclimatized and their sweat $\mathrm{N}$ concentrations remained unchanged as the experiment proceeded. The values came at the lower limit of the range found among previous workers, but contrary to the findings in many other investigations the amount of $\mathrm{N}$ in the sweat was very similar from one subject to another and the values did not show a wide scatter.

Acclimatization may therefore be of considerable importance in relation to the amount of $\mathrm{N}$ lost in sweat, and the results of studies carried out in temporary and artificial hot environments in temperate climates may not be applicable to persons living in tropical countries. Lack of acclimatization may have been responsible for the high sweat $\mathrm{N}$ values previously found, and these may have been further exaggerated if arm-bag collections were used.

One of the aims of the experiment in Jamaica was to investigate whether there was any decrease in urinary $\mathrm{N}$ to compensate for the $\mathrm{N}$ losses in the sweat. Consolazio, Nelson et al. (1963) found no evidence of renal compensation, but Daly \& Dill (1937) showed a marked decrease in urinary $\mathrm{N}$, compared with a control period, whilst sweating was in progress.

In this experiment in Jamaica there was a fall in urinary $\mathrm{N}$ during the heavy- 
sweating period 2 compared with the control period I. This decrease, however, can be attributed to the change in diet rather than to sweating, because the urinary $\mathrm{N}$ output in period I was probably still being affected by the high $\mathrm{N}$ intake before the beginning of the experiment. This could have been avoided if the subjects had received the experimental diet several days beforehand, so that a steady state would have been reached at the beginning of period $I$.

A better comparison for determining the effect of sweating on urinary $\mathrm{N}$ excretion is the difference between periods 3 and 4 . During the heavy-sweating period 4 the mean urinary $\mathrm{N}$ excretion fell by $0.5 \mathrm{I} \mathrm{g}$ when compared with that in the minimalsweating period 3 . This might be regarded as a compensation for the $0.48 \mathrm{~g} \mathrm{~N}$ lost in the sweat. But examination of the individual values showed that in three subjects there were increases in urinary $\mathrm{N}$ excretion in period 4 , and in three subjects there were decreases; these decreases, in fact, overcompensated for the sweat $\mathrm{N}$ loss. However, the $\mathrm{N}$ losses in sweat were so small that they were close to the limits of experimental accuracy in balance measurements. It is therefore difficult to determine whether there was in fact any compensatory decrease in urinary $\mathrm{N}$ output as a result of sweating.

The effect of sweating on urinary $\mathrm{Na}$ excretion was very marked and there was clear-cut evidence of renal compensation. During the heavy-sweating periods 2 and 4 the amounts of $\mathrm{Na}$ lost in sweat were 70 and $59 \mathrm{~m}$-equiv. The urinary excretion during these two periods fell by 72 and 89 m-equiv. compared with the values for periods I and 3 , so that a positive $\mathrm{Na}$ balance was maintained despite the sweat loss.

There was also a decrease in urinary $\mathrm{K}$ during sweating, but the compensation was not as precise as that for Na. During the sweating periods 2 and 4 the $\mathrm{K}$ losses in the sweat were 27 and $\mathrm{I} 8 \mathrm{~m}$-equiv., and the corresponding decreases in urinary $\mathrm{K}$ were 6 and $3 \mathrm{I}$ m-equiv.

In view of the fact that the subjects lost, on average, less than $0.5 \mathrm{~g} \mathrm{~N} /$ day in approximately 31 . of sweat, and since within the limits of experimental error they maintained $\mathrm{N}$ balance on intakes of $5 \circ \mathrm{g}$ protein/day, it is concluded that profuse sweating does not warrant more than marginal increases in the protein allowances for people in tropical countries.

We thank Professor J. C. Waterlow who initiated this study following the discussions of the WHO/FAO Expert Group on Protein Requirements. Professor Waterlow has taken an active part in the design of the study and with the analyses. We are indebted to Dr E. E. Ward for providing the subjects and thank him for helping with the design and analyses. We are especially grateful to Francis Blackman, Lloyd Cole, Curtis Cox, Neville McMillan and Douglas Welds who were energetic and cheerful volunteers. We thank them for their co-operation and enthusiasm and for the careful and conscientious way in which they kept their records. Finally, we should like to thank Dr J. S. Garrow who helped one of us with many preliminary investigations on sweat collection and composition. 


\section{REFEIRENCES}

Bass, D. E., Kleeman, C. R., Quinn, M., Henschel, A. \& Hegnauer, A. H. (1955). Medicine 34, 323.

Consolazio, C. F., Johnson, R. E. \& Pecora, L. J. (1963). Physiological Measurements of Metabolic Functions in Man. New York: McGraw-Hill Book Company Inc.

Consolazio, C. F., Matoush, L. O., Nelson, R. A., Isaac, G. J. \& Canham, J. E. (ig66). Am. F. clin. Nutr. I8, 443 .

Consolazio, C. F., Nelson, R. A., Matoush, L. O., Harding, R. S. \& Canham, J. E. (I963). F. Nutr. 79, 399.

Daly, C. \& Dill, D. B. (1937). Am. F. Physiol. 118, 285.

Kleeman, C. R., Bass, D. E. \& Quinn, M. (1953). F. clin. Invest. 32, 736.

Ladell, W. S. S. (1948). F. Physiol., Lond. 107, 465 .

Mickelsen, O. \& Keys, A. (1943). F. biol. Chem. 149, 479.

Mitchell, H. H. \& Edman, M. (1962). Am. F. clin. Nutr. 1o, r63.

Molnar, G. W., Towbin, E. J., Gosselin, R. E., Brown, A. H. \& Adolph, E. F. (1946). Am. F. Hyg. 44, 4II.

Robinson, S. \& Robinson, A. H. (1954). Physiol. Rev. 34, 202.

Scrimshaw, N. S., Habicht, J. P., Piché, M. L., Cholakos, B. \& Arroyave, G. (1966). Am. F. clin. Nutr 18,321 .

van Heyningen, R. \& Weiner, J. S. (1952). F. Physiol., Lond. r16, 395. 